\title{
Improving Amounting Ability Through Media Power Points in Grade II of Basic School
}

\section{Siti Marwah}

SDN Pedeslohor 02

sitimarwah7718@gmail.com

\section{Article History}

accepted 01/11/2020

approved 08/11/2020

published 15/11/2020

\begin{abstract}
The problem that arises in this classroom action research is the low ability of students in learning addition. The purpose of this study was to develop learning steps using power point media to improve student learning outcomes. This classroom action research was the subject of second grade students of SDN Pedeslohor 02 semester I of the 2020/2021 school year. With 12 students, this classroom action research was conducted in 2 cycles, each cycle consisting of 4 stages, namely planning, implementing, observing and reflecting. The method of collecting research data is through tests and observations. The data analysis used quantitative descriptions. The results showed that through the power point media it could improve students' ability in addition. The average value of student learning outcomes in the pre-cycle was 60.9 and in the first cycle it reached 73.5 while the second cycle became 81 . It can be concluded that through power point media it can improve students' learning ability.
\end{abstract}

Keywords: Ability, addition, power point media.

\begin{abstract}
Abstrak
Permasalahan yang muncul dalam penelitian tindakan kelas ini adalah masih rendahnya kemampuan siswa dalam pembelajaran penjumlahan. Tujuan penelitian ini adalah untuk mengembangkan langkah-langkah pembelajaran menggunakan media power point untuk meningkatkan kemampuan hasil belajar siswa. Penelitian tindakan kelas ini dengan subjek siswa kelas II SDN Pedeslohor 02 semester I tahun pelajaran 2020/2021. Dengan jumlah siswa 12 orang, penelitian tindakan kelas ini dilaksanakan dalam 2 siklus, setiap siklus terdiri 4 tahap yaitu perencanaan, pelaksanaan, observasi dan refleksi. Cara pengumpulan data penelitian ini yaitu melalui tes dan observasi. Analisis datanya menggunakan deskripsi kuantitatif. Hasil penelitian menunjukan bahwa melalui media power point dapat meningkatkan kemampuan siswa dalam penjumlahan. Nilai rata-rata hasil belajar siswa pada pra siklus 60,9 dan pada siklus I mencapai 73,5 sedangkan siklus II menjadi 81. Dengan demikian dapat disimpulkan bahwa melalui media power point dapat meningkatkan kemampuan belajar siswa.
\end{abstract}

Kata kunci : Kemampuan, Penjumlahan, media power point.

Social, Humanities, and Education Studies (SHEs): Conference Series https://jurnal.uns.ac.id/shes

p-ISSN 2620-9284

e-ISSN 2620-9292 


\section{PENDAHULUAN}

Berdasarkan hasil pengamatan peneliti dan didukung oleh pendapat rekan guru kelas II SDN Pedeslohor 02 diketahui bahwa dalam mengerjakan soal - soal muatan pelajaran matematika tentang penjumlahan dengan tekhnik menyimpan bersusun panjang dan pendek masih kurang memuaskan. Hal ini dapat terlihat dari aktivitas siswa yaitu Siswa tidak bisa menjumlahkan dengan teknik menyimpan dengan cara bersusun panjang maupun pendek, Siswa merasa jenuh dan tidak tertarik saat mengikuti pembelajaran, Hasil evaluasi siswa sebagian besar masih dibawah KKM. Peneliti berupaya melakukan perbaikan dengan penelitian tindakan kelas atau Classroom Action Research. Penelitian tindakan kelas adalah bentuk penelitian yang terjadi di dalam kelas berupa tindakan tertentu yang dilakukan untuk memperbaiki proses belajar mengajar guna meningkatkan hasil belajar yang lebih baik dari sebelumnya. Menurut Arikunto, dkk (2006), penelitian tindakan kelas merupakan suatu pencermatan terhadap kegiatan belajar berupa sebuah tindakan, yang sengaja dimunculkan dan terjadi dalam sebuah kelas secara bersama. Sedangkan menurut Menurut Supardi (2006), penelitian tindakan kelas adalah penelitian yang mampu menawarkan cara dan prosedur baru untuk memperbaiki dan meningkatkan profesionalisme pendidik dalam proses belajar mengajar di kelas dengan melihat kondisi siswa. Penelitian tindakan kelas dapat berjalan dengan baik apabila dalam perencanaan dan pelaksanaannya menerapkan enam prinsip, yaitu sebagai berikut (Hopkins, 1993):

Tugas pertama dan utama guru di sekolah adalah mengajar siswa sehingga apapun metode penelitian tindakan kelas yang akan diterapkan tidak akan mengganggu komitmen sebagai pengajar. Metode pengumpulan data yang di gunakan tidak menuntut waktu yang berlebihan dari guru sehingga berpeluang mengganggu proses pembelajaran. Metodologi yang digunakan harus cukup reliable sehingga memungkinkan guru mengidentifikasi serta merumuskan hipotesis secara cukup meyakinkan, mengembangkan strategi yang dapat diterapkan pada situasi kelasnya dan memperoleh data yang dapat digunakan untuk menjawab hipotesis yang di kemukakannya. Masalah penelitian yang diusahakan oleh guru seharusnya merupakan masalah yang merisaukannya. Bertolak dari tanggung jawab profesionalnya, guru sendiri memiliki komitmen yang diperlukan sebagai motivator intrinsik bagi guru untuk bertahan dalam pelaksanaan kegiatan yang jelas-jelas menuntut lebih dari yang sebelumnya diperlukan dalam rangka pelaksanaan tugas-tugas pengajarnya. Dalam menyelenggarakan penelitian tindakan kelas, guru harus selalu bersikap konsisten menaruh kepedulian tinggi terhadap prosedur etika yang berkaitan dengan pekerjaannya. Hal ini penting ditekankan karena selain melibatkan anak-anak, penelitian tindakan kelas juga hadir dalam suatu konteks organisasional sehingga penyelenggaraannya harus mengindahkan tata krama kehidupan berorganisasi. Kelas merupakan cakupan tanggung jawab seorang guru, namun dalam pelaksanaan penelitian tindakan kelas sejauh mungkin digunakan classroom excedding perspektive, artinya permasalahan tidak dilihat terbatas dalam konteks dalam kelas atau mata pelajaran tertentu,melainkan dalam perspektif yang lebih luas ini akan berlebih-lebih lagi terasa urgensinya apabila dalam suatu penelitian tindakan kelas terlibat dari seorang pelaku.

Menurut Hopkins (1993), penelitian tindakan kelas diawali dengan perencanaan tindakan (Planning), penerapan tindakan (action), mengobservasi dan mengevaluasi proses dan hasil tindakan (Observation and evaluation). Sedangkan prosedur kerja dalam penelitian tindakan kelas terdiri atas empat komponen, yaitu perencanaan (planning), pelaksanaan (acting), pengamatan (observing), dan refleksi (reflecting), dan seterusnya sampai perbaikan atau peningkatan yang diharapkan tercapai (kriteria keberhasilan). Penelitian ini untuk meningkatkan kemampuan belajar siswa tentang 
penjumlahan. Kemampuan juga bisa disebut dengan kompetensi. Kata kompetensi berasal dari bahasa Inggris "competence" yang berarti ability, power, authotity, skill, knowledge, dan kecakapan, kemampuan serta wewenang. Jadi kata kompetensi dari kata competent yang berarti memiliki kemampuan dan keterampilan dalam bidangnya, sehingga ia mempunyai kewenangan atau otoritas untuk melakukan sesuatu dalam batas ilmunya tersebut. Kemampuan dalam hal menjumlahkan, Menurut Kamus Besar Bahasa Indonesia (KBBI), Menjumlahkan adalah menghitung berapa banyaknya, atau sesuatu yang dikumpulkan menjadi satu. Sedangkan pada kata jumlah dalam Kamus Besar Bahasa Indonesia (2003 : 480) artinya banyaknya untuk bilangan atau sesuatu yang dikumpulkan menjadi satu, sedangkan penjumlahan adalah proses, cara, perbuatan menjumlahkan. Pembelajaran penjumlahan artinya mengajarkan sesuatu kepada anak didik dengan melalui media penjumlahan. Djamarah $(2008:: 213)$ mengatakan media adalah segala bentuk serta saluran menyampaikan pesan maupun informasi untuk meningkatkan kemampuan belajar siswa dapat menggunakan media pembelajaran seperti microsoft power point. Menurut Jelita (2010) microsoft Power Point adalah suatu software yang akan membantu dalam menyusun sebuah presentasi yang efektif, professional, dan juga mudah.

Media powerpoint bisa membantu sebuah gagasan menjadi lebih menarik dan jelas tujuannya jika dipresentasikan karena media powerpoint akan membantu dalam pembuatan slide, outline presentasi, presentasi elektronika, menampilkan slide yang dinamis, termasuk clipart yang menarik, yang semuanya itu mudah ditampilkan di layar monitor komputer. Melalui media power point sehingga pembelajaran dapat interaktif antara guru dan siswa, siswa terlibat aktiv dan antusias saat mengikuti pembelajaran dan siswa merasa tidak bosan dan dapat meningkatkan pemahaman, dengan demikian pemanfaatan media power point dapat meningkatkan kemampuan belajar siswa tentang penjumlahan dengan tekhnik menyimpan dengan cara panjang dan pendek.

\section{METODE}

Jenis penelitian yang di gunakan adalah penelitian tindakan kelas (Classroom Action Research), yaitu penelitian yang dilakukan oleh guru di sekolah atau di kelas dengan penekanan pada penyempurnaan atau peningkatan proses dan praktik pembelajaran (dalam Aqib :2006). Lokasi yang digunakan untuk penelitian tindakan kelas ini adalah SD Negeri Pedeslohor 02 kelas II semeter I tahun pelajaran 2020/2021. Waktu penelitian ini dilaksanakan pada semester ganjil tahun pembelajaran 2020/2021. Yaitu mulai Oktober sampai November 2020 dan dilakukan melalui beberapa tahap diantaranya tahap persiapan, tahap pelaksanaan, dan tahap penyusunan. Adapun yang menjadi subjek penelitian tindakan kelas ini adalah siswa kelas II SD Negeri Pedeslohor 02 sebanyak 12 siswa dengan komposisi 5 siswa lakilaki dan 7 siswa perempuan. Metode pengumpulan data berupa tes, diperlukan untuk mengukur tingkat ketercapaian tindakan sebagai sumber belajar dalam meningkatkan kemampuan hasil belajar muatan pelajaran matematika materi tentang penjumlahan. Teknik tes dilakukan pada akhir pembelajaran dengan menggunakan lembar soal tes evaluasi. Tes yang digunakan adalah tes tertulis yang berbentuk tes uraian penjumlahan dengan tekhnik bersusun panjang dan pendek untuk mengukur pemahaman siswa pada ranah kognitif. Metode analisis data terdiri atas dua data, yaitu analisis ketuntasan dan analisis komparatif hasil belajar.

\section{HASIL DAN PEMBAHASAN}

Berdasarkan hasil observasi awal pada muatan pelajaran matematika, banyak siswa yang mendapatkan nilai di bawah Kriteria Ketuntasan Minimal (KKM). 
Hasil observasi pada kondisi awal yang diperoleh dari ulangan harian dalam pembelajaran matematika diperoleh data dari 12 siswa yang mengikuti evaluasi pembelajaran terdapat 3 siswa (25\%) mampu mencapai KKM (75) dan 9 siswa (75\%) masih berada dibawah KKM. Adapun hasil belajar siswa pada kondisi awal adalah sebagai berikut.

Tabel 1. Hasil Evaluasi Pembelajaran Pra Siklus

\begin{tabular}{|c|c|c|c|}
\hline Nilai $(\mathrm{n})$ & $\begin{array}{c}\text { Banyaknya } \\
\text { Siswa }(\mathrm{F})\end{array}$ & $\mathrm{n} \times \mathrm{F}$ & Persentase \\
\hline 50 & 3 & 150 & $25 \%$ \\
\hline 60 & 5 & 300 & $42 \%$ \\
\hline 65 & 1 & 65 & $8 \%$ \\
\hline 75 & 2 & 150 & $17 \%$ \\
\hline 76 & 1 & 76 & $8 \%$ \\
\hline Jumlah & 12 & 741 & 100 \\
\hline Rata-rata & & 62 & \\
\hline Tuntas & & $25 \%$ & \\
\hline Tidak Tuntas & & $75 \%$ & \\
\hline
\end{tabular}

Berdasarkan tabel di atas, dari 12 siswa yang belum mencapai KKM ada 9 siswa (75\%), sedangkan siswa yang mencapai KKM ada 3 siswa (25\%). Hasil belajar kondisi awal masih jauh dari yang diharapkan, maka perlu diadakan tindakan untuk meningkatkan hasil belajar siswa sesuai dengan pencapaian ketuntasan belajar klasikal minimal 80\% dengan nilai KKM mencapai kurang dari 65.

\section{Deskripsi siklus I}

\section{Perencanaan}

Adapun perencanaan yang telah disiapkan dalam pembelajaran siklus I adalah: menyusun perangkat pembelajaran, memilih model pembelajaran yang sesuai dengan karakter anak dan menggunakan media sehingga anak akan mudah menginggat pembelajaran yang sudah diajarkan, menyusun lembar observasi sebagai panduan bagi observer terdiri dari lembar observasi aktivitas siswa dan lembar observasi aktivitas guru, menyusun lembar kerja siswa dan menyusun alat penilaian hasil belajar siswa.

Pelaksanaan

Pada siklus I ini, guru menjelaskan materi pelajaran tentang penjumlahan dengan tekhnik menyimpan dengan cara bersusun panjang dan pendek melalui media power point dengan kegiatan terdiri dari kegiatan pendahuluan, kegiatan inti dan di akhiri dengan evaluasi berupa tes kemampuan individu untuk mengetahui kemampuan hasil belajar.

\section{Pengamatan}

Secara umum perhatian siswa terhadap penyajian materi melalui media power point cukup baik, beberapa siswa diam saja sambil menyaksikan, ada juga salah satu anak bermain sendiri. Pengamatan terhadap kemampuan siswa mengerjakan soal dapat dilihat pada hasil evaluasi diakhir siklus I sebagai berikut:

Tabel 2. Hasil Evaluasi Pembelajaran Siklus I

\begin{tabular}{|c|c|c|c|}
\hline Nilai $(\mathrm{n})$ & $\begin{array}{c}\text { Banyaknya } \\
\text { Siswa }(\mathrm{F})\end{array}$ & $\mathrm{n} \times \mathrm{F}$ & Persentase \\
\hline 50 & 1 & 50 & $8 \%$ \\
\hline 60 & 2 & 120 & $17 \%$ \\
\hline 65 & 1 & 65 & $8 \%$ \\
\hline
\end{tabular}




\begin{tabular}{|c|c|c|c|}
\hline 70 & 1 & 70 & $8 \%$ \\
\hline 75 & 1 & 75 & $8 \%$ \\
\hline 80 & 3 & 80 & $25 \%$ \\
\hline 85 & 3 & 85 & $25 \%$ \\
\hline Jumlah & 12 & 875 & \\
\hline Rata-rata & & 72,91 & \\
\hline Tuntas & & $58 \%$ & \\
\hline Tidak Tuntas & & $42 \%$ & \\
\hline
\end{tabular}

kurang dari Kriteria Ketuntasan Minimal $(\mathrm{KKM}=75)$ sebanyak 5 siswa atau 42\%, sedangkan yang sudah mencapai ketuntasan minimal sebanyak 7 siswa dengan persentase 58\%. Dari jumlah keseluruhan 12 siswa dengan nilai rata-rata 73,5 dan nilai tertinggi 85 serta nilai terendah 50 .

Refleksi

Dari tabel 2. Dapat diketahui bahwa prosentase ketuntasan belajar baru mencapai $58 \%$. Hal tersebut memberikan gambaran bahwa indikator keberhasilan belum tercapai. Oleh karenanya penelitian dilanjutkan dengan siklus II dengan diadakan beberapa perbaikan atau tindakan.

\section{Deskripsi Siklus II}

\section{Perencanaan}

Berdasarkan hasil refleksi pada siklus I merekomendasikan untuk diadakan perbaikan atau tindakan. Adapun perbaikan yang dilakukan adalah menggunakan power point interaktif yang didalamnya terdapat video pembelajaran dan disertai animasi yang menarik dan melakukan Tanya jawab ketika pembelajaran sedang berlangsung sehingga siswa terlibat aktif.

\section{Pelaksanaan}

Pada siklus II peserta didik menyimak video pembelajaran yang terdapat pada power point yang terkait dengan penjumlahan kemudian melakukan Tanya jawab yang berkaitan pembelajaran dilanjutkan guru menunjuk salah satu siswa secara bergilir untuk maju ke depan kelas, kegiatan ini bertujuan untuk mengukur pemahaman siswa terhadap materi yang sudah ditayangkan melalui power point.

\section{Pengamatan}

Selama proses pembelajaran dengan media power point interaktif siswa dapat terlibat aktif dalam pembelajaran. Adapun hasil evaluasi siswa pada kegiatan pembelajaran siklus II seperti tercantum pada tabel berikut:

Tabel 3. Hasil Evaluasi Pembelajaran Siklus II

\begin{tabular}{|c|c|c|c|}
\hline Nilai $(\mathrm{n})$ & $\begin{array}{c}\text { Banyaknya } \\
\text { Siswa }(\mathrm{F})\end{array}$ & $\mathrm{n} \times \mathrm{F}$ & Persentase \\
\hline 50 & 1 & 50 & $8 \%$ \\
\hline 60 & 1 & 60 & $8 \%$ \\
\hline 70 & 1 & 70 & $8 \%$ \\
\hline
\end{tabular}




\begin{tabular}{|c|c|c|c|}
\hline 78 & 1 & 78 & $8 \%$ \\
\hline 80 & 4 & 320 & $33 \%$ \\
\hline 100 & 4 & 400 & $33 \%$ \\
\hline Jumlah & 12 & 978 & \\
\hline Rata-rata & & 81 & \\
\hline Tuntas & & $75 \%$ & \\
\hline Tidak Tuntas & & $25 \%$ & \\
\hline
\end{tabular}

Berdasarkan tabel di atas terlihat bahwa siswa yang memiliki nilai kurang dari KKM sebanyak 3 siswa atau $25 \%$, sedangkan yang sudah mencapai ketuntasan minimal sebanyak 9 siswa dengan persentase 75\%. Dari jumlah keseluruhan 12 siswa dengan nilai rata-rata 81 dan nilai tertinggi 100 serta nilai terendah 50 .

Refleksi

Dengan melihat tabel 3. Dapat diketahui bahwa presentase ketuntasan secara klasikal adalah $75 \%$. Hal tersebut memberikan gambaran bahwa indikator keberhasilan dapat di capai.

\section{Pembahasan antar siklus}

Berdasarkan hasil pengamatan dan analisis data yang ada, dapat dilihat adanya peningkatan aktivitas guru dan aktivitas siswa dalam pembelajaran. Berikut ini dapat dilihat hasil rekap perkembangan hasil belajar tiap siklus.

\section{Tabel 4. Hasil Belajar Siswa Tiap Siklus}

\begin{tabular}{|l|c|c|c|}
\hline \multicolumn{1}{|c|}{ Keterangan } & $\begin{array}{c}\text { Pra } \\
\text { Siklus }\end{array}$ & Siklus I & Siklus II \\
\hline Jumlah Nilai & 731 & 882 & 978 \\
\hline Rata-rata & 60,9 & 73,5 & 81 \\
\hline Siswa yang tuntas & 3 & 7 & 9 \\
\hline Siswa yang tidak tuntas & 9 & 5 & 3 \\
\hline Persentase Siswa yang Tuntas & $25 \%$ & $58 \%$ & $75 \%$ \\
\hline $\begin{array}{l}\text { Persentase Siswa yang tidak } \\
\text { Tuntas }\end{array}$ & $75 \%$ & $42 \%$ & $25 \%$ \\
\hline Nilai Tertinggi & 80 & 85 & 100 \\
\hline Nilai Terendah & 50 & 50 & 50 \\
\hline $\begin{array}{l}\text { Hasil Perkembangan } \\
\text { Berdasarkan Prosentase }\end{array}$ & Turun & Naik & Naik \\
\hline
\end{tabular}

Dari tabel hasil belajar pengelompokan nilai pada tabel di atas dapat dilihat adanya peningkatan jumlah siswa yang tuntas. Kenaikan ketuntasan dapat dilihat dari hasil rekap persiklus dalam tabel hasil perkembangan belajar siswa berdasarkan prosentase.

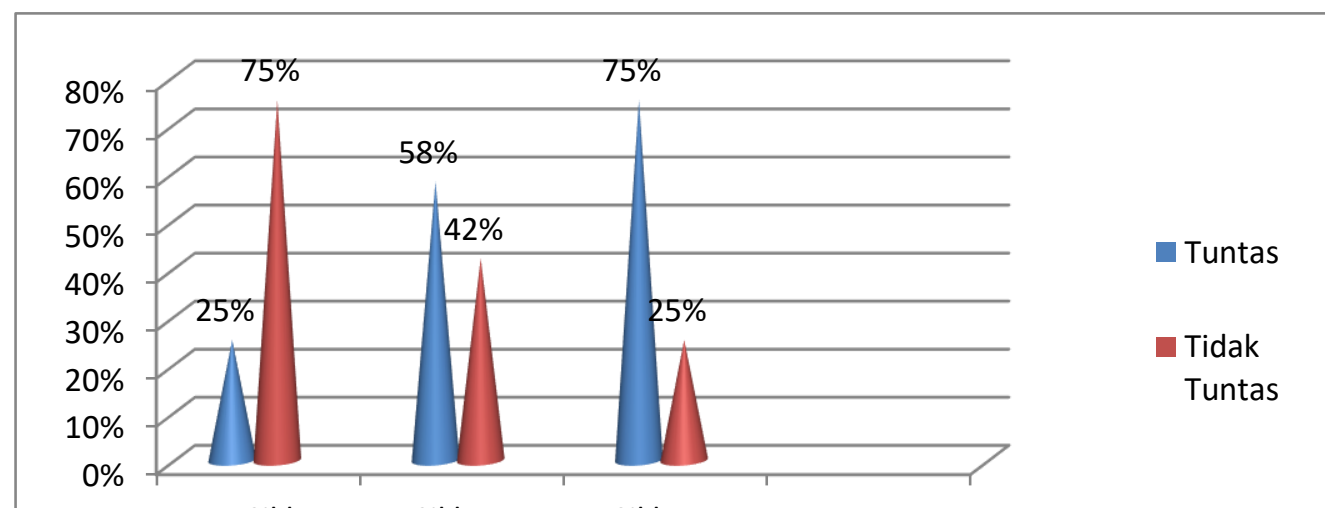




\section{Gambar 1. Ketuntasan Hasil Belajar Pra Siklus, Siklus I, Siklus II}

Pada hasil analisis penelitian di atas menunjukan bahwa pembelajaran menggunakan media power point dapat meningkatkan kemampuan belajar siswa. Perubahan peningkatan hasil belajar sesuai yang di ungkapkan oleh Menurut Arsyad (2011), penggunaan media pembelajaran di dalam proses belajar mengajar memiliki beberapa manfaat sebagai berikut:

1. Media pembelajaran dapat memperjelas penyajian pesan agar tidak terlalu bersifat verbalitas (dalam bentuk kata-kata tertulis atau lisan belaka) sehingga siswa tidak bosan dan guru tidak kehabisan tenaga.

2. Dengan menggunakan media pembelajaran secara tepat dan bervariasi dapat diatasi sikap pasif dan dalam hal ini media power point dapat berguna untuk: menimbulkan motivasi belajar siswa; memungkinkan interaksi yang lebih langsung antara anak didik dengan lingkungan dan kenyataan.

\section{SIMPULAN}

Berdasarkan hasil penelitian dan pembahasan dapat disimpulkan bahwa menggunakan media power point dapat meningkatkan aktivitas dan hasil belajar muatan pembelajaran matematika dengan materi tentang penjumlahan dengan tekhnik menyimpan dengan cara pendek dan panjang pada siswa kelas II SD Negeri Pedeslohor 02 Kecamatan Adiwerna Kabupaten Tegal. Hal ini ditunjukan dengan: Peningkatan hasil belajar siswa. Pada pra siklus, siswa yang tuntas hanya 3 siswa $(25 \%)$ dengan nilai rata-rata adalah 60,9 . Pada Siklus I, siswa yang tuntas sebanyak 7 siswa (58\%) dengan nilai rata-ratanya adalah 73,5 . Pada siklus II siswa yang tuntas sebanyak $9(75 \%)$ siswa dan tidak tuntas 3 siswa atau $25 \%$ dengan nilai rata-ratanya adalah 81

Berdasarkan hasil simpulan di atas, maka beberapa saran yang dapat dipergunakan adalah sebagai berikut. Bagi guru, diharapkan dalam pembelajaran dapat menggunakan media yang tepat. Salah satunya adalah menggunakan media power point yang terbukti dapat meningkatkan hasil muatan pembelajaran matematika. Dalam melaksanakan kegiatan pembelajaran sebaiknya guru menguasai materi dengan baik sehingga dapat memusatkan perhatian kepada siswa. Bagi sekolah, pihak sekolah diharapkan mampu untuk mengembangkan pembelajaran dengan menggunakan media power point pada muatan pembelajaran lainnya.

\section{DAFTAR PUSTAKA}

Arikunto, Suhardjono dan Supardi.2006.Penelitian Tindakan Kelas.Jakarta: Bumi Aksara

Arsyad, Azhar.2011.Media Pembelajaran.Jakarta: Rajawali Pers

Aqib, Zainal, dkk.2011.Penelitian Tindakan Kelas untuk Guru SD, SLB, dan TK. Bandung : Yrama Widya

Djamarah.2008.Guru dan Anak Didik.Jakarta:Penerbit Rineka Cipta 
Hopkins, David.1993.A Teacher's Guide to Classroom Research.Philadelphia : Open University Press

https://kbbi.kemdikbud.go.id/entri.menjumlahkan di akses 18 November 2020 https://bahtraedu.wordpress.com/2015/05/02/media-pembelajaran-power-point/ di akses 9 Oktober 2020 